\title{
Berhane Hewan ('Light for Eve'): Increasing opportunities to delay marriage and promote schooling
}

Annabel Erulkar

Population Council

Eunice N. Muthengi

Population Council

Follow this and additional works at: https://knowledgecommons.popcouncil.org/departments_sbsr-pgy

Part of the Demography, Population, and Ecology Commons, Family, Life Course, and Society

Commons, Gender and Sexuality Commons, Gender Equity in Education Commons, and the International

Public Health Commons

How does access to this work benefit you? Let us know!

\section{Recommended Citation}

Erulkar, Annabel and Eunice N. Muthengi. 2012. "Berhane Hewan ('Light for Eve'): Increasing opportunities to delay marriage and promote schooling," policy brief. Addis Ababa: Population Council. 


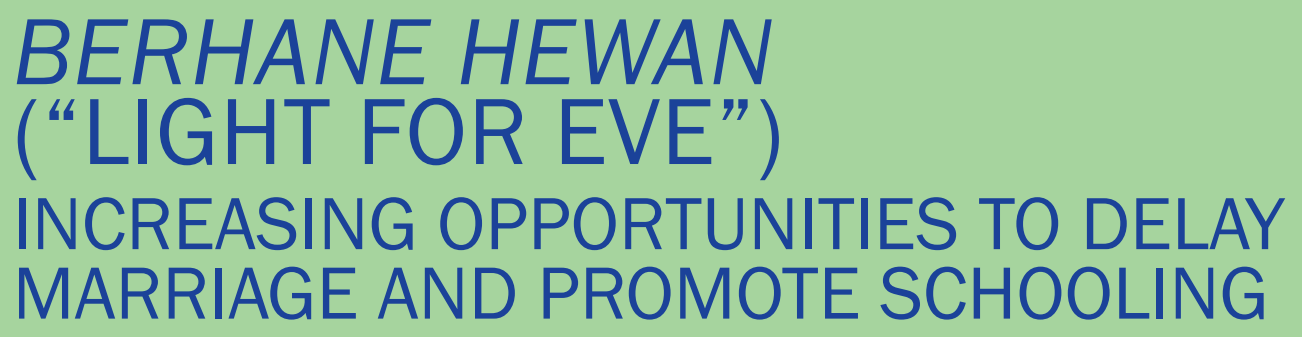

\section{BY ANNABEL ERULKAR AND EUNICE MUTHENGI-KAREI}

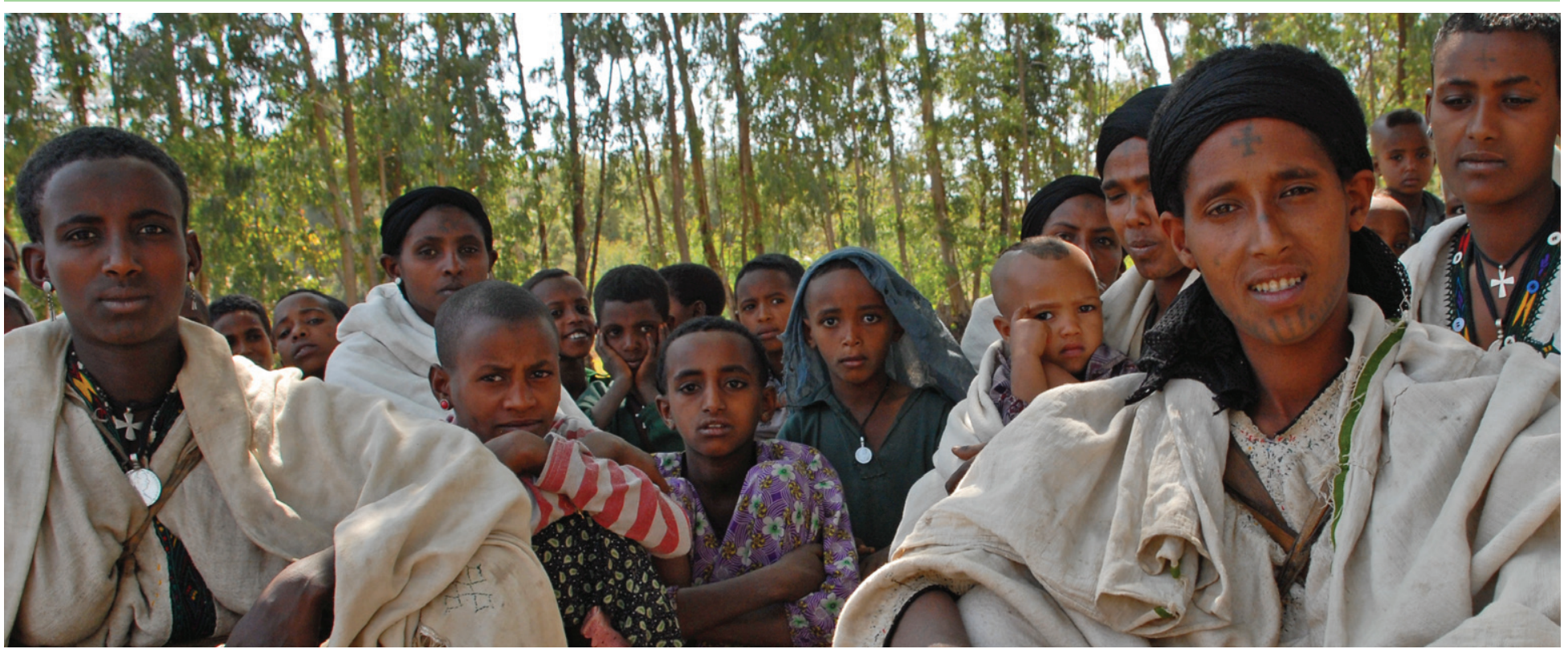

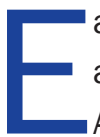

arly marriage, defined as marriage before the age of 18 , is mainly practiced in sub-Saharan Africa and South Asia, where more than one-third of African girls and nearly one-half of South Asian girls are married during childhood (Brown 2012).

In sub-Saharan Africa, the highest rates of child marriage are found in West Africa, in countries such as Chad, Mali, and Niger. In East Africa, however, the number of early marriages in countries such as Ethiopia, Malawi, and Zambia is also substantial. Whereas the legal marriage age in Ethiopia is 18, the median age at marriage among rural girls is 17.3 , and $14 \%$ are married before their 15th birthday (Population Council 2011; CSA and ICF Macro 2012). ${ }^{1}$

This policy brief describes girls' experience of early marriage, education, and sexual behavior in rural Amhara Region, Ethiopia. Findings are drawn from a baseline study conducted in 2011, in rural Awi zone of the Amhara Region. Approximately 2,500 girls aged 12 to 17 were interviewed, as well as more than 500 parents.
We also discuss efforts in the region to delay marriage and promote girls' schooling.

\section{EARLY MARRIAGE IN AMHARA REGION, ETHIOPIA}

Among girls in rural Awi zone, one in five (18\%) are married by age 15 , and nearly half (44\%) are married by age 17 (Figure 1). Marriage in these highland communities is an arrangement between families. Only $8 \%$ of girls reported that they chose to marry, while the vast majority of marriages (92\%) were arranged. When asked about giving girls choice in marriage, most parents reported that they would not give their daughters the choice of when to marry (57\%) or whom to marry (62\%).

Many of these early marriages end in divorce. More than half of ever-married girls in the survey were divorced or separated (53\%). Arranged marriages were more likely to be dissolved (56\%), compared with those that were chosen (35\%). 
FIGURE 1 Cumulative proportion of 12-17-yearold girls in Awi zone, Amhara, who are ever-married, by age

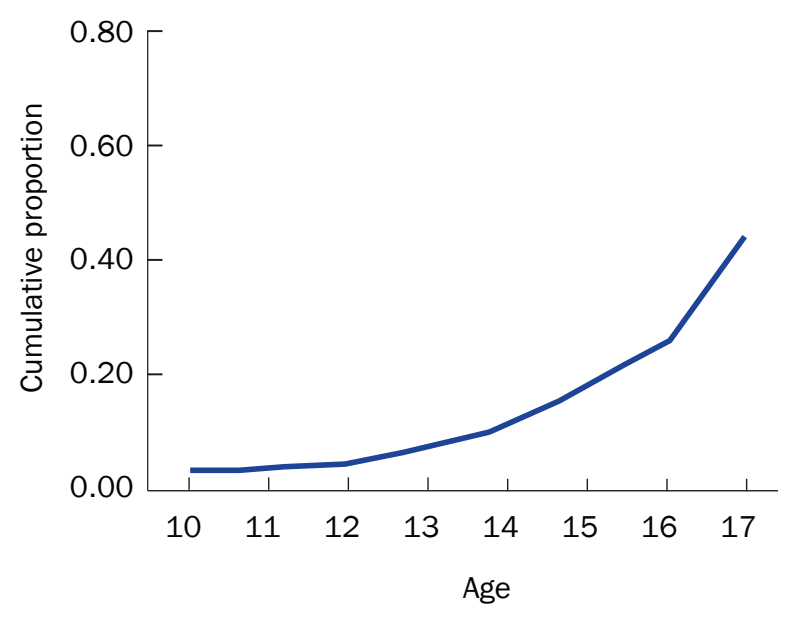

\section{LOW LEVELS OF EDUCATION, ESPECIALLY AMONG GIRLS WHO MARRY EARLY}

Educational enrollment and attainment was relatively low among married girls in Awi zone. Overall, $7 \%$ of girls had never been to school, and married girls were four times more likely to have no education (21\%) compared with unmarried girls (5\%). The main reasons cited for never having been to school differed between girls who were married and those who were not (Table 1). Among ever-married girls, $30 \%$ cited marriage as the reason for not attending school. In addition, girls who were married were significantly more likely to report that their parents do not see the benefit of schooling. More than $90 \%$ of girls who had never attended school would have liked to get an education.

On average, girls in rural Awi zone achieved five years of schooling. Girls started school quite late. With seven as the official school entry age in Ethiopia, only $28 \%$ of school-going girls started on time; $44 \%$ started at age eight or nine, and $28 \%$ started at age ten or older.

\section{THE TERMS OF EARLY MARRIAGE UNDERMINE GIRLS' AGENCY}

Married girls' low levels of education barely equip them for adult roles in marriage, and the terms of early marriage also undermine girls in those relationships. Most married girls (73\%) did not know about the marriage beforehand, and $76 \%$ met their husband for the first time on their wedding day.

The younger a girl is when she marries, the more likely there will be a large age difference with her husband (Mensch, Bruce, and Greene 1998). Girls who are significantly younger than their spouses typically experience limited power and decisionmaking within their relationships (Levine et al. 2008). Average spousal age difference was seven years among girls married before age 15, and five years among girls married at age 15 or older. Married girls with much older husbands were less likely to report discussing reproductive health topics with them (Figure 2).

The majority of sexually experienced girls were married girls. Less than $1 \%$ of never-married girls had ever had sex. Sexual initiation was extremely early and frequently nonconsensual. Fifty-four percent of married girls had first sex before the age of 15 . Nearly half (49\%) reported that their marital sexual initiation was forced, and $43 \%$ had not started menstruating at the time of their sexual initiation. Fifty-four percent of girls reported that they were unable to refuse their husband sex. One-fourth of girls worried that their spouse would give them HIV, and one in five suspected that their husband had been unfaithful.

\section{EARLY MARRIAGE AND REPRODUCTIVE HEALTH}

Adolescent girls are frequently too young physically, emotionally, and developmentally for pregnancy. Births

TABLE 1 Reasons for girls aged $12-17$ never attending school, by marital status $(n=159)^{\text {a }}$

\begin{tabular}{lcc}
\hline & Never-married girls (\%) & Ever-married girls (\%) \\
\cline { 2 - 2 } Family could not afford schooling & 37.5 & 34.9 \\
Parents do not see the benefit of schooling & 21.9 & $36.5^{*}$ \\
School too far & 11.5 & 3.2 \\
Too many domestic responsibilities & 20.8 & 14.3 \\
Got married & 0.0 & $30.2^{* * *}$ \\
Death of parent(s) & 8.3 & 12.7 \\
Sickness or disability & 13.5 & 4.8 \\
\hline
\end{tabular}

*Significant at $p<0.05 ; * * * p<0.001$ a Percentages sum to more than $100 \%$ because multiple responses were possible. 


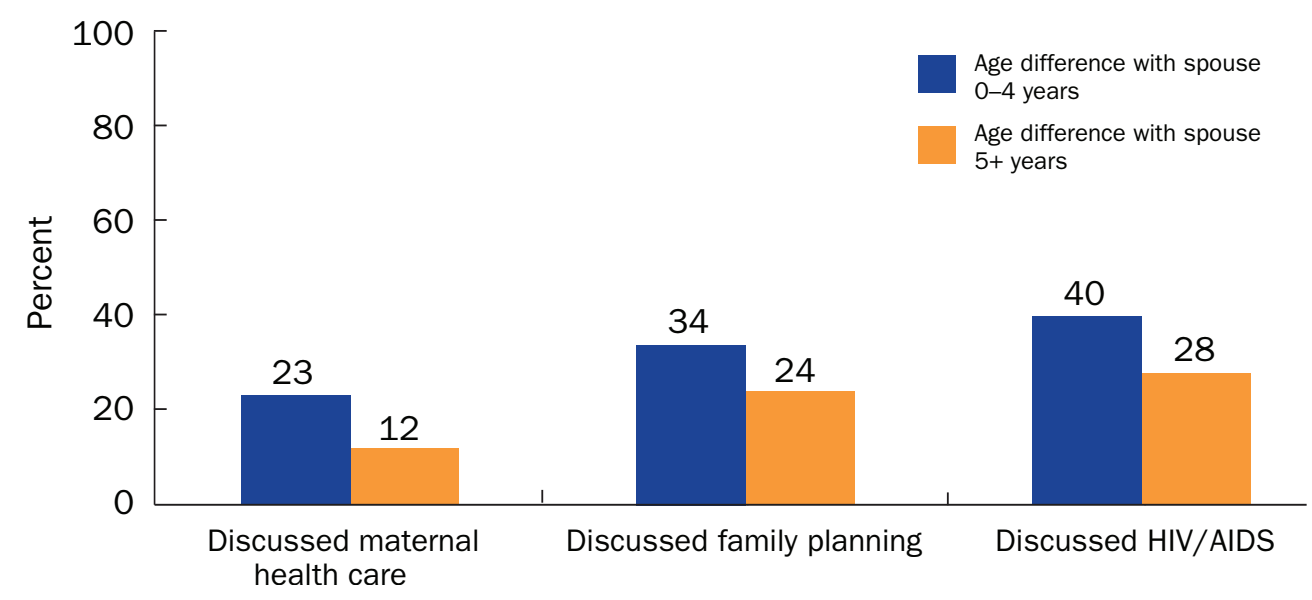

among young mothers are associated with increased risk of preterm birth, infant mortality, maternal mortality, and maternal morbidities such as obstetric fistula (Nour 2006). In Ethiopia, almost all adolescent births occur within the context of marriage. About one out of seven (15\%) sexually experienced, married girls had given birth or were pregnant at the time of the survey. Almost all births (93\%) occurred at home and only half of young mothers (53\%) reported that they saw a health professional for prenatal care during their first pregnancy.

Among married girls, $50 \%$ had used a family planning method. The most common method was injectables/ Depo. There was high unmet need for family planning; $46 \%$ of currently married girls who were not using a method reported that they would like to use family planning. In addition, many young mothers reported having unintended pregnancies. At the time of their first pregnancy, $32 \%$ of mothers preferred to delay the pregnancy by at least a year, and $8 \%$ did not want to be pregnant at all.

\section{BERHANE HEWAN: INCREASING OPPORTUNITIES TO DELAY MARRIAGE AND PROMOTE SCHOOLING}

Early marriage has a significant impact on girls' health, well-being, and personal development. Girls who marry early are already disadvantaged. They tend to come from poor backgrounds and have little or no education. Research in Awi zone, Ethiopia, shows that a considerable proportion of girls who married early have only limited discussions regarding health issues with their spouses, experience forced and nonconsensual sex, and have high unmet need for family planning. Early marriage leads to early childbearing which, in turn, leads to elevated health risks. Increasing the age at which girls are married would result in brides who are better prepared for marriage, and marriages that are more equitable, safe, and healthy.

From 2004-06, the Amhara Bureau of Women, Children and Youth Affairs (ABWCY) and the Population Council pilot-tested a program to delay marriage and support schooling in rural Amhara region. The program, entitled Berhane Hewan (Amharic for "Light for Eve"), included community conversations, support for remaining in school, and conditional cash transfers if girls remained unmarried and in school for the duration of the two-year pilot. An evaluation at the end of the pilot showed significant improvements. Compared with girls aged 10-14 in the control site, girls in the project site were one-tenth as likely to be married and three times more likely to be in school (Erulkar and Muthengi 2009). Because a package of interventions had been implemented, however, researchers found it difficult to ascertain which program component was most influential in delaying marriage and promoting schooling.

In this next phase of Berhane Hewan, the various strategies to delay marriage and promote schooling will be tested in different districts ("woredas"), enabling researchers to assess the impact of each. As in the pilot, the activities will include: community awareness, support for getting girls back into school and keeping them there, and conditional cash transfers (Figure 3). Costing data will also be collected. 


\begin{tabular}{|c|c|c|}
\hline Driver of early marriage & Strategy & Program model \\
\hline $\begin{array}{l}\text { Culture, religion, } \\
\text { social norms; lack of } \\
\text { awareness }\end{array}$ & $\begin{array}{l}\text { Awareness-raising } \\
\text { for parents and } \\
\text { communities }\end{array}$ & $\begin{array}{l}\text { Community conversations led by } \\
\text { trained facilitators, including } \\
\text { religious leaders }\end{array}$ \\
\hline $\begin{array}{l}\text { Lack of girls' } \\
\text { educational and } \\
\text { livelihood opportunities }\end{array}$ & $\begin{array}{l}\text { Promotion of girls' } \\
\text { education and } \\
\text { livelihood capabilities }\end{array}$ & $\begin{array}{l}\text { Provision of school supplies } \\
\text { (notebooks, pens, and pencils) }\end{array}$ \\
\hline $\begin{array}{l}\text { Poverty and economic } \\
\text { incentives to marry girls }\end{array}$ & $\begin{array}{l}\text { Incentives to keep girls } \\
\text { unmarried }\end{array}$ & $\begin{array}{l}\text { Conditional cash transfers of } \\
\text { about ETB } 250 \text { (US\$14) }\end{array}$ \\
\hline
\end{tabular}

Community conversations led by trained facilitators and/or religious leaders will be used to sensitize communities on the importance of education and the risks to girls who marry early. In selected project sites, unmarried girls will be eligible to receive educational support in the form of school materials, in exchange for parental assurance that they will not arrange a marriage and will attempt to keep their daughters in school. Finally, social transfers worth about 250 ETB (US\$14) will be provided to families in some sites if they keep girls unmarried during the 30-month period. After two years, surveys will again be undertaken in Awi zone to measure the impact of various strategies on marriage age, educational participation, and reproductive-health behavior, among others.

\section{NOTE}

1 Analysis of DHS data among rural females aged 20-24.

\section{REFERENCES}

Brown, G. 2012. "Out of wedlock, into school: Combating child marriage through education." London: The Office of Gordon and Sarah Brown.

Central Statistical Agency (CSA) [Ethiopia] and ICF Macro. 2012. Ethiopia Demographic and Health Survey 2011 (EDHS 2011). Addis Ababa, Ethiopia, and Calverton, MD: CSA and ICF Macro.

Erulkar, A., E. Muthengi. 2009. "Evaluation of Berhane Hewan: A program to delay marriage in rural Ethiopia," International Perspectives on Sexual and Reproductive Health 35(1): 6-14.

Levine, R., C. Lloyd, M. Greene, and C. Grown. 2008. Girls Count: A Global Investment \& Action Agenda. Washington, DC: Center for Global Development.

Mensch B., J. Bruce, and M. Greene. 1998. The Uncharted Passage: Girls' Adolescence in the Developing World. New York: Population Council.

Nour, N.M. 2006. "Health consequences of child marriage in Africa," Emerging Infectious Diseases 12(11): 1644-1649.

Population Council tabulations of EDHS 2011.

\section{For more information, contact: \\ ANNABEL ERULKAR \\ Country Director \\ Population Council \\ P.O. Box 25562, \\ Code 1000 \\ Addis Ababa, ETHIOPIA

\author{
ZIMAM ASSEFA \\ Bureau Head \\ Amhara National Regional State, \\ Bureau of Women, Children and Youth Affairs \\ P.O. Box 1238 \\ Bahir Dar, ETHIOPIA
}

\author{
ALEMESEGED WOLDEGERIMA \\ Core Process Owner \\ Amhara National Regional State, \\ Bureau of Women, Children and Youth Affairs \\ P.O. Box 1238
} \\ Bahir Dar, ETHIOPIA}

aerulkar@popcouncil.org

\section{For additional resources, visit www.popcouncil.org}

The Population Council confronts critical health and development issues-from stopping the spread of HIV to improving reproductive health and ensuring that young people lead full and productive lives. Through biomedical, social science, and public health research in 50 countries, we work with our partners to deliver solutions that lead to more effective policies, programs, and technologies that improve lives around the world. Established in 1952 and headquartered in New York, the Council is a nongovernmental, nonprofit organization governed by an international board of trustees. 